\title{
St Paul's Anglican Theological College during the Transition towards a Democratic South Africa, 1986-92
}

\author{
Henry Mbaya \\ University of Stellenbosch \\ hmbaya@sun.ac.za
}

\section{ABSTRACT}

St Paul's Theological College was established in Grahamstown, South Africa, in 1902 to train white Anglican students for the ministry. During the last six years of its existence, from 1986 to 1992, the college went through rapid changes: emerging new trends in theological training and ministry raised questions on the relevance of traditional patterns of training in which St Paul's College had been established and operated from. Although the College was originally intended to exclusively train white students, during this period, the numbers of black students started to balance off with those of white students, just as the number of women ordinands also started to rise. On the other hand, financial challenges facing some dioceses also adversely affected the college. In the dying days of apartheid, the college became more involved in the sociopolitical issues of Grahamstown. Moreover, its enduring image as a "white" college in the emerging new South Africa seemed an embarrassment to the church authorities. The closure of St Paul's College, and its merger with St Bede's College on the premises of St Paul's College, paved the way for a new College of the Transfiguration (COT), which was an attempt to respond some of these challenges.

Keywords: Anglican; black; church; St Paul's College; democracy; students; South Africa; white; College of the Transfiguration (COT); St Bede's College

UNISA 


\section{INTRODUCTION}

The aim of this research article ${ }^{1}$ is to document a history of one of the major Anglican theological colleges in South Africa, St Paul's Theological College, which was based in Grahamstown. Specifically, the paper will highlight the impact of the policy and practices of apartheid, as well as the new trends in ministry and theological education on the college's life during the last six years of its existence, in the years between 1986 and 1992. It was a period which was particularly significant precisely because St Paul's College was going through considerable transformation, from being an exclusively white college before 1976 to being 50 per cent black and also increasingly training female ordinands. As such, the paper seeks to highlight the challenges that the college was confronting as it gave way to the start of the new college, called "College of the Transfiguration".

St Paul's College had been established as an Anglican theological college in Grahamstown in the Eastern Cape in 1902, to train European male candidates for the priesthood. ${ }^{2}$ It was one of the three theological colleges of the Anglican Church in South Africa, alongside St Bede's in Mthatha and St Peter's of the Federal Theological Seminary. From 1976 to the time of its closure in 1992, the college had been training black students as well.

\section{THE DEPARTURE OF DUNCAN BUCHANAN}

In 1985, Duncan Buchanan, warden of the college since 1976, announced to the college that he had been appointed dean of the diocese of Johannesburg. On 6 March 1985 at the college award ceremony, Philip Russell, Archbishop of Cape Town, announced that Chichele Hewitt would succeed Buchanan. He went on and stated that:

I want to say that I am delighted with his appointment for several reasons, but not least is that I believe that the College will prosper greatly under him. He is a good leader, a man of real compassion and understanding, a good administrator and very wise. He will, I know, keep the vision of the College which we have sought to foster, and is so radically

\footnotetext{
1 This article is based on the last chapter of my forthcoming book, Resistance and Acquiescence to Apartheid: St Paul's Theological College, 1965-92.

2 ACT X, Constitution and Trust Deed of St Paul's College, AB 2568 B 4, 1983-86 [emphasis in original document]. Historical Papers, Research Archives, UWL.
} 
different from me that no one must dare to try and compare us. I love him very much, and I am sure that the right choice was made under God. Please pray for Chich and his wife Gill, their daughters, Clare and Inger, as they make the same move that we madefrom 117 Durban Street to Cullen House. ${ }^{3}$

Buchanan had been in the college for 20 years, the first 10 years as sub-warden and the rest as warden. Buchanan trusted Hewitt for obvious reasons. Hewitt had been chaplain and lecturer under Buchanan's leadership and had been a former student of the college. Buchanan's commendations were intended to inspire confidence in the college where he had worked for 20 years as sub-warden and warden. ${ }^{4}$

\section{A NEW ERA: A NEW VISION}

In this new context, Hewitt brought in fresh vision and insights. Hewitt became warden in context of the state of emergency which had been imposed in 1985. It was also during the time when petty apartheid laws were being abolished. In his Warden's Report to the College Council in 1986, Hewitt also made a very important announcement. He pointed out that:

There was great rejoicing at this election when St Paul's College elected its first African Senior Student, [Lawrence Zola Mathebula] ... Some of the old issues will resurface, and this will include debating the sports policy where, hopefully, sport will be played with regularity of 1986. New freedom in non-racial facilities resulted in some good sporting activities last year, which did a great deal for the College. ${ }^{5}$

Lawrence Mathebula was the first black African senior student, that is, the head student of the student body. He became a senior student during the time when blacks were expected to increasingly take on leadership in the society that seemed to be slowly opening up. In addition, Mathebula assumed leadership at a time when the college was going through tension regarding how to commemorate June 16.

ACT X, Constitution and Trust Deed of St Paul's College, AB 2568 B 4, 1983-86.

Personal reminiscences, 1984-1987.

Warden's Letter, 27 November, 1986, AB2568, A 4, St Paul's College, 1983-91. Historical Papers, Research Archives, UWL. 


\section{THE COMMEMORATION OF SOWETO: JUNE 16 IN 1986}

June 16, as was Sharpeville Day, were marked days in the college calendar. Hewitt recalled that every year when June 16 was approaching, there was always anxiety as to how the occasions would be celebrated. ${ }^{6}$ Early in 1986, the college faced such situation. Hewitt recalled that "very early in his post", the college made a decision in the Common Room to march to the township where the students and members of staff would attend worship at the Order of Ethiopia. ${ }^{7}$ In his report to the College Council in 1986, he said:

Remarkably, June $16^{\text {th }}$ was the occasion when there was the greatest sense of unity in the College. Not that it was easy getting there. As the $10^{\text {th }}$ Anniversary of June $16^{\text {th }} 1976$ was approaching, there was a feeling in the College that more than a quiet day spent in prayer was required in identifying with the greater part of Grahamstown people. The declaration of a State of Emergency forced the College into long debate, with a meeting on Sunday June $15^{\text {th }}$ running into the next morning. Most of the College, it was agreed, would proceed to the township to attend a service of worship while some would remain behind to pray. This decision was arrived at with no sense of division between the two groups and as we met at a final Eucharist of Celebration on the evening of June $16^{\text {th }}$, it was evident that the Lord had been with us and worked strongly that day. ${ }^{8}$

This writer witnessed this incident. ${ }^{9}$ Even though there was no sense of division, there was a sense of fear of the unknown, for example, what would happen if the police shoot? It was a terrifying experience passing through heavily armed Caspirs. One had the feeling that the presence of whites (staff and students), somehow seemed to have a restraining effect on the white soldiers often known for their brutal treatment of blacks. Emotions were running high. ${ }^{10}$

By the end of the year, in his Warden's Letter, Hewitt highlighted how the situation in the country was affecting the college. Hewitt stated that:

Telephone interview with Chichele Hewitt, 17 March, 2016.

The Order of Ethiopia had a historic relationship with the Anglican Church (see Peter Hinchliff, The Anglican Church in South, London: Darton, Longman \& Todd, 1963, p. 200-203.

8 Warden's Report (end of 1986) to St Paul's College Council, AB2568, A 4, St Paul's College, 1983-91. Historical Papers, Research Archives, UWL.

9 Personal Reminiscences, 1986-1987.

10 Personal Reminiscences, 1986-1987. 
These challenges face us all, as Christians, and not least at St Paul's. On June $16^{\text {th }}$ with a new declared state of emergency, the College spent a long but profitable time debating how the day was to be used. A great spirit of unity was felt as members of the College attended a service in the township followed by a service at the Commemoration Methodist Church. The day concluded with a Eucharist in the College Chapel where we could truly give thanks to God for the way he had guided us. However much a theological college differs from the reality of parish life, it is South Africa in microcosm, and a training scheme to be undertaken, which hopefully, will be relevant in a changing society. As we need to pray for you, so I hope you will pray for us. Because where men and women are being trained for full-time service in Christ, there one is in the fore front of a spiritual battle. ${ }^{11}$

South Africa had lived under a state of emergency since 1985. In 1986, the Anglican Church declared apartheid a heresy. ${ }^{12}$ This was the context in which the march to the township took place in 1986. It was within this context that in his Warden's Letter of August 1987, Hewitt gave a brief report about the 'Mission' trip that he had led to Queenstown earlier that year, the story to which we now turn.

\section{MISSIONS IN 1987: APARTHEID IN THE GRAVE YARD?}

In that letter, Hewitt stated that "... [He] had a wonderful and supportive team, and [they] ... were given the opportunity of ministering in the so-called white and coloured parishes of Queenstown." He related the rest of the story as follows:

We learnt a great deal in the week away, many people were reached, and lives were changed. During the week a parishioner died and some of us were privileged to attend the funeral. There was something memorable and moving as we stood in the cemetery with its backdrop of trees and mountains, including the enormous "Hangklip". Even in death a fence separates a White and Black, but Christ has defeated death and has broken

11 Warden's Letter 1986 to Friends, 27 November, 1986. AB2568, A 4, St Paul's College, 1983-91. Historical Papers, Research Archives, UWL.

12 Warden's Letter 1986 to Friends, 27 November, 1986. AB2568, A 4, St Paul's College, 1983-91. Historical Papers, Research Archives, UWL. 
down dividing walls between people, and in the joys and sorrows of the past week, we saw people reaching for one another in Christ. ${ }^{13}$

It was the absurdity of the apartheid policy that enforced separation along racial lines even in death. It was an extension of the implementation of the Group Areas Act (Act 41 of 1950) or the Reservation of Separate Amenities Act (Act 49 of 1953). In that same year, Torquil Paterson, of the staff members, recalled to have led a multiracial team on mission to Fort Beaufort. He said that he allocated white students to live with black members of the congregation. His intention, so he recalled, was to expose whites to blacks' experience of apartheid in township. ${ }^{14}$ Paterson said he was not sure whether that had any effect on the white students' attitudes to the sufferings of blacks under apartheid. ${ }^{15}$ It is highly unlikely that a one week stay with black people in rural South Africa would have radically changed the whites' racial attitudes which had taken apartheid and white communities years to instil.

\section{NEW CHALLENGES FACING THEOLOGICAL EDUCATION}

Challenges facing the college with regard to the mode of theological training went back to the 1960s. In that era, Trevor Verryn's The Vanishing Clergyman characterised the challenge facing ministry and theological training. It was in this context that Hewitt reported that at the end of 1987:

Torquil Paterson presented a vision for St Paul's College which we had discussed as a staff. The basis of his approach is the recognition of the frenetic pace at College, and a way forward. Simply put, Torquil [Paterson] suggests a ten-month year, closer to the experience from which most have come and into which most will be going. The pace within this will be forcibly slower, and there will be compulsory rest periods, and a one subject per day scheme. There will be also a greater involvement in the local community, and a greater emphasis on rural ministry, including some community projects e.g. vegetable growing. ${ }^{16}$

\footnotetext{
Warden's Letter, August, 1987. AB 2568, A 4, 1983-91. Historical Papers, Research Archives, UWL. Skype Interview with Torquil Paterson, 2 March, 2016.

Skype Interview with Torquil Paterson, 2 March, 2016.

Warden's Report, Council Minutes, February, 1988, AB2568, A 4, St Paul's College, 1987-92. Historical Papers,
} Research Archives, UWL. 
One dimension of Paterson's vision entailed opening the college to social community engagement. It would seem that Paterson was presenting an alternative approach to what Marilyn Naidoo termed as a "Theological education [that] heavily emphasise[d] learning that takes place in the classroom, and [is] focussed on knowledge production ..."17 Naidoo termed this "a scholastic or seminary model ${ }^{18}$... [e]mbedded in the process of scholastic learning." Naidoo views this as "field education or supervised ministry with a view to providing students with the necessary skills they will be assuming in ministry ..."19 Naidoo concludes by observing that "[t]hese are generally designed to act as a bridge between the theological education and the church. It involves a twofold charge: to assess the integrity of a student's calling to ministry and to facilitate the professional readiness of the student."20

Behind the approach proposed by Paterson lay a very ancient and important principle: orare et labora, a context of theological training where prayer life finds expression in and is complemented with work in community. It would seem that according to Hewitt, the thrust of Paterson's approach was the critical role that context played in equipping ordinands with skills and expertise for ministry.

Naidoo highlighted the critical role of context in ministerial formation thus, "[t]he education of the clergy needs to engage the pedagogies of contextualisation that heighten students' awareness of the dynamic character of the content and agency ..." ${ }^{21}$ Naidoo went on to assert that "contexts as settings of human interaction have content", consisting of "patterns of relationship and social structures." Naidoo finds that "meaning and identity are always contextual" and that "content is hidden unless contexts become accessible to critical and open to transformation." 22 In relation to St Paul's College, Hewitt observes that:

The staff are not unaware of a number of disadvantages, as well as the obvious advantages of such a scheme and have already met with 6 invited guests, each an expert in the particular area relevant to the College life, in an attempt to test the feasibility of such a scheme. Some of the suggestions have already been adopted on a trial basis,

17 Marilyn Naidoo, "Ministerial Training: The need for pedagogies of formation and of contextualisation in theological education" Missionalia 3 (November 2010) 347-368.

18 Naidoo, "Ministerial Training", 347-368.

19 Naidoo, "Ministerial Training", 347-368.

20 Naidoo, "Ministerial Training", 347-368

21 Naidoo, "Ministerial Training", 347-368

22 Naidoo, "Ministerial Training", 347-368 
including personal tutorials, and the abandoning of Sunday worship in Chapel so that students will get involved in local parishes. ${ }^{23}$

The envisaged scheme considered a greater exposure to life in the community as a critical aspect of this form of training. Exposure to community would facilitate the college to engage with practical issues in the society. In the following year, this development took on another dimension. Hewitt reports that:

At the beginning of 1988, led by Dr Jim Cochrane from Natal University, he explored [for the college] the possibility of a new paradigm in Theological Education ... We were all excited about new things that are emerging from this ... new method[s], a new visitor, ... these are essential in these difficult times in which we live. ${ }^{24}$

The new paradigm involved not only pedagogy but also a new perspective on authority structures in the church with regard to the role of the priest. It is also significant to note that in 1988, Hewitt announced to the College Council that Njumbuxa Bikitsha had joined the college staff. ${ }^{25}$ Bikitsha was the first black African member of staff since Zolile Mbali had resigned in 1974. It is quite striking that it took five years since Bishop Desmond Tutu had recommended (in 1983) the appointment of a black lecturer in light of the racial crisis of 1982.

\section{RIFE WITH TENSION 1989}

\section{Amongst students}

In his Warden's Report of 18 February 1990 to the college, Hewitt reported about the tensions that had occurred on every level of college life in the year 1989, which he attributed to the situation in the country. Hewitt stated that:

There were also tensions [in 1989] within the student body. There is nothing new about this, and within South Africa of 1989. It would have been surprising were this not so.

23 Warden's Report, Council Minutes, February, 1988, AB2568, A 4, St Paul's College, 1987-92. Historical Papers, Research Archives, UWL.

24 ACT X, Constitution and Trust Deed of St Paul's College, AB 2568 B 4, 1983-86.

25 ACT X, Constitution and Trust Deed of St Paul's College, AB 2568 B 4, 1983-86. 
There was obvious polarisation in the first year class, although its constituent members worked hard at relationships. The final year class, was however, much more difficult. People had taken up entrenched positions, and were not prepared to change. Some were just waiting for the year to end, and there was a feeling of negativity, which has not been experienced for some time ... The College, nevertheless, worked through this in quite a creative way.

In the late 1980s, South Africa experienced intense racial polarisation which was reflected in the life of the students in the college. It impacted on students' relationships and their attitudes towards one another. The leadership of the senior student made a considerable difference in putting out the fires. In that report, Hewitt further observed that:

Mr Thabo Makgoba was a member of that class, and he was Senior for 1989. Thabo [Makgoba] is an outstanding person with great leadership skills, and were it not for him there would inevitably have been a few more "incidents" last year. He had the ability to sort out some of these in their early stages, before they affected the whole community ... In conclusion it is abundantly clear that something new must happen. It is likely that numbers will continue to drop, and while there is as yet no clear Provincial direction as to which way we are moving, the pattern of present seminary training may soon be a thing of the past ... ${ }^{26}$

Thabo Cecil Magkoba, (who later became the Bishop of Grahamstown and Archbishop of Cape Town), was a student at St Pauls College from 987 to 1989. Makgoba was very much a likeable person who easily socialised with fellow students. He came across as a very sharp and deep person. ${ }^{27} \mathrm{He}$ was gifted with a warm personality, ability to unravel intricate issues, ability to command confidence of students on the opposing sides, and a visionary leader. ${ }^{28}$ His election as senior student seemed to testify to his excellent leadership skills, which were subsequently affirmed by the Church when he was elected Bishop of Grahamstown and then Archbishop of Cape Town in $2010 .^{29}$

26 Warden's Report, 18 February, 1990, Minutes of St Paul's College Council, 15 March, 1990, AB 2568. Historical Papers, Research Archives, UWL.

27 Personal Reminiscences, 1984-1987.

28 Personal Reminiscences, 1984-1987.

29 Personal Reminiscences, 1984-1987. 
It is very likely that the instability amongst the staff was one of the most painful experiences that the college was going through at this time.

\section{Amongst staff}

Hewitt asserted:

The academic staff situation was obviously more complex than usual. 3 of the 5 members who began the year together had left before the year was out. We had known for some time that the Revd. Fred Hendricks would be leaving in July to take up a parish appointment in the Cape Town Diocese after a period of long leave. At the beginning of his leave, he married Miss Dorothea Thorne, and the joy of this occasion was mingled with the sadness of leaving someone who had given so much to St Paul's. Fred was a fine teacher - a man of wisdom and prayer, and a trusted colleague. His support will be solely missed. Miss Stella Bavier has been with us since 1982, and felt that her time on the teaching staff had come to an end. She also took long leave prior to leaving the staff, but is staying on at the College as a paying guest while she begins studies at Rhodes University. She, too, has given of her considerable gifts, and her contribution will also be missed. Stella has not found her last 2 years at College easy, but has nevertheless given of her energy and many will miss her, not only as a teacher, but also as a friend. ${ }^{30}$

Hewitt also announced the departure of Paterson as follows:

Canon Torquil Paterson also announced his resignation in the final week of last term. Because he had resigned his licence, his departure from staff followed very quickly, although he too is staying on at College for this year; he will not be teaching at all, but will continue as College Librarian. This will be of great help to us all, because he knows the library well, and has made a huge contribution to its new order over the past 3 years. His departure has been a great loss to us all, and has not been without its difficulty. Torquil was brilliant if not a controversial teacher and preacher, and while some lived for lecturers, others were repulsed by its content. ${ }^{31}$

30 Warden's Report, 18 February, 1990, Minutes of St Paul's College Council, 15 March, 1990, AB 2568. Historical Papers, Research Archives, UWL.

31 Warden's Report, 18 February, 1990. Minutes of the Diocesan Council, 15 March, 1990. 
The departure of three members of staff at the same time suggests serious underlying issues in the college. In this respect, it is noteworthy that Hewitt acknowledged both Paterson and Bavier as not having had an easy time, especially in the last two years of their service at the college. It would appear that these lecturers were experiencing personal challenges that also naturally affected their relationships with others in the college. However, the situation regarding Paterson seemed even more dramatic and desperate. Hewitt concludes that:

As a result [Paterson] and the College came in for a lot of fire from within and without. He himself was struggling with the new directions of faith, and his great integrity would not eventually permit him to remain as an Anglican priest, even though he says he will always be a theologian...$^{32}$

Paterson was going through a kind of crisis of faith which made it difficult for him to continue teaching the Christian faith with a sense of integrity. Recalling this incident on 17 March 2016, Hewitt spelt out varied reactions to Paterson's journey. He said that Archbishop Tutu "was quite sympathetic about Torquil's position, though he insisted that he could not remain teaching" but then suggested that "he could stay in one of the clergy houses." 33 Tensions in the student body and personal challenges of faith cannot be isolated from tensions in the wider community. At the height of apartheid, the question of the relevance of the Christian faith (or any religion) constituted part of the wider struggle in grappling with the meaning of one's life in South Africa.

\section{FINANCES AND THE FUTURE 1989}

Meanwhile, the worsening financial position of the college seemed to correlate with the decline in the numbers of the students. The financial situation in the college appeared more uncertain. In his report, Hewitt observes that:

While the College's financial situation looks less secure this year owing to a smaller intake than expected, we face an issue of major concern. It would seem that numbers

32 Warden's Report, 18 February, 1990. Minutes of the Diocesan Council, 15 March, 1990.

33 Telephone interview with Chichele Hewitt, 17 March, 2016. 
are dropping at all our residential seminaries. If this trend continues (as it looks like doing) all attempts at containing costs within the boundaries of inflation with be thwarted.

A forecast of 1990 produced a very gloomy picture of the future of the college. Hewitt pointed out that:

In 1990, 50 students would result in annual fees of about R6 000 per student. Sadly, the number of students for 1990 looks like being 40, and may even drop lower. As a result, the budget has been cut quite drastically, and we hope to contain the fees at R7 000 per student; this may still result in a deficit for 1990. This is very serious, because there is every likely-hood of a "vicious circle" developing. Numbers decline, costs rise proportionally, and it becomes more difficult to pay those coming forward, leading to a further decline in numbers.

More significantly, Hewitt put this challenge within a wider problem of the crisis that faced theological education. He notes that:

This is just one aspect of a severe crisis which must be addressed in Theological Education. Despite this crisis, we continue, with our sister Colleges, to seek new ways in theological education, especially with regard to methodology and syllabi. At the last meeting of the Joint Board for Diploma in Theology, there seem to be a genuine interest in the whole matter, and a committee with staff and student representation from each of the participating Colleges will be meeting under the Chairmanship of the Revd Canon Torquil Paterson. ${ }^{34}$

At the centre of the crisis was the question of the relevance of the traditional mode of theological training. Traditional residential training was seen to be not very relevant to the modern pattern of ministry-where the "authority" of the priest seemed to be waning and the pattern of ministry changing. Hewitt merely scratched the surface of a deeper crisis in theological education. Naidoo outlines the problem as follows:

34 Warden's Report, Minutes of St Paul's College Council, AB 2568, B 5, 1987-92. Historical Papers, Research Archives, UWL. 
The most pressing challenge affecting theological education is the consensus of contemporary literature that theological education is in a crisis ... Concerns about the state of theological education persist: the curriculum is specialised and fragmented, this hindering the equipping of leaders; a coherent purpose and compelling vision for theological education are lacking; historically, the effort to integrate the curriculum around theology has been lost; theology itself is undefined, fragmented, rationalised and specialised; theory and practice are in perpetual tension ... the analysis of the problem is that theological institutions have failed to produce the desired product, a skilled leader, or that the purpose of theology is not understood and therefore the theological curriculum is in disarray with minimal integration among the disciplines and a tendency to functionalism. ${ }^{35}$

Here, Naidoo locates the problem within a wider framework. There was no real integration between theological training (curriculum) in the seminary and ministry in church (and society). These issues impacted on the calibre of clergy that the college produced. A question can then be asked as to why this was the case. The answer to this lies in the fact that traditional theological pedagogies and frameworks within which St Paul's College operated, were developed down the centuries in Europe and were now out of step with the changes that had occurred in church and society in the recent years in South Africa. As such, the changes in church and society called for an overhaul of whole systems; a complete orientation of theological education and ministerial training. One of these changes related to the issue of human sexuality.

\section{HUMAN SEXUALITY AND GENDER}

During an interview with this author on 17 March 2016, Hewitt recalled that one of the issues that emerged in the last years of St Paul's College was human sexuality. In his view, this was part of the power struggle that raged between white and black students. Hewitt stated:

The issue of sexuality was quite a rough one. I remember clearly the incident. Ivan Toms who belonged to the Evangelical Church in Wynberg came to speak at St Paul's. He was a medical doctor and he was very popular for the work in the black and coloured

35 Marilyn Naidoo, "Ministerial Training”, 350-351. 
community. He came to speak in the college about resisting the army; about half-way through his address he said there is another issue I want to speak about. "I am a gay person." He then spoke about the difficulties that he had had-coming from an Evangelical background; he said people had laid hands on him in the Evangelical Churches but nothing had happened about it ... ${ }^{36}$

Additionally, Hewitt recalled that: "He had another huge anger in the college from this [conservative] white group ... There was a strong feeling that I should have stopped him." Hewitt, however, remarked that he "didn't know what black people thought about the issue ..."37

The issues that arise from the episode narrated by Hewitt are significant. First, the fact that Ivan Tom is said to have declared his sexuality half-way through the address, almost as an "after-thought", suggests the struggle that he was going through. This was indicative of the struggle that many like him were also going through, among them Douglas Torr.

During the interview with the author, Torr, a former student of the college in the years 198587, reminded this author that "[t]here was another dimension to life in the college [that I had not raised during the interview], the contested arena of sexuality." Torr said: "I don't believe that we ever dealt with this area" and that "there was no way I would have come out. I felt very much isolated. Politics was for our lives; I couldn't share that with Duncan [Buchanan] ...”38 Desmond Tutu highlights the attitude of the church of that time when he observes that:

The Church of Jesus Christ, far from being inclusive and welcoming of all, has over and over again pushed many to the periphery; instead of being hospitable to all, it has made many of God's children outcasts and pariahs on the basis of something which, like race or gender, they could do nothing - their sexual orientation. The church has joined the world in committing what I consider to be the ultimate blasphemy - making the children of God doubt that they are children of God. ${ }^{39}$

36 Telephone interview with Chichele Hewitt, 17 March, 2016.

37 Telephone interview with Chichele Hewitt, 17 May 2016.

38 Interview with Douglas Torr, Bramley, Johannesburg, 12 June, 2014.

39 Desmond Tutu, "Foreword," in Paul Germond and Steve de Gruchy, (eds.), Aliens in the Household of God. Cape Town and Johannesburg: David Philip, 1997. 
The issue of homosexuality cannot be unrelated to the issue of justice, human rights and, by implication, human dignity precisely because of the fundamental Christian imperative of the law of love. Ian Corbett put it like this: "It is essential that the churches respond, not only that justice may be done to the homosexual community, but also for the sake of church itself. God is Love, says St John. But, as the former bishop of Durham lamented, 'the Church has never understood this basic principle of its founder': it has never really sought to live by love; it has found the prospect altogether too threatening and subversive." ${ }^{40}$ Even more fundamental, the issue is related to the doctrine of creation, the core of which is that all human beings are created in the image of God.

\section{ON THE THRESHOLD OF THE NEW ERA: 1990-1992}

Early in 1990, Mr F.W. de Klerk, the then State President, announced the release of Mr Nelson Mandela and other political prisoners and the unbanning of some political organisations. The announcement ushered in optimism and great expectations. In his Warden's Letter of 1 December 1990, Hewitt states that:

I have likened the past year to a flight which was remarkably smooth, even though the take-off and landing were bumpy! The new initiatives of the Government brought about different dynamics in the College, but we all continue to learn new lessons about living in a non-racial environment ... The future of Theological Education has many minds for much of the year, and various meetings have taken place in the Church. False rumours have been rife about the College closing. Let me set the record straight. At the Award Ceremony in March, I said that numbers at all our Colleges were dropping, and if this pattern continued, the Province might have to adopt a policy of rationalisation. This could involve St Paul's College or any of the other Colleges closing or combining. ${ }^{41}$

It was in this context that rumours were rife of the impending closure of the college. Bailey recalled being called by Hewitt who told him that he (Hewitt) had heard that he (Bailey) was

40 Ian D. Corbett, "Homosexuality in the traditions of the Church," in Paul Germond and Steve de Gruchy, (eds.), Aliens in the Household of God. Cape Town and Johannesburg: David Philip, 1997. p. 170.

41 Warden's Letter, December, 1990. AB 2568, A 4, St Paul's College, 1983-91, Historical Papers, Research Archived, UWL. 
praying for the "closure" of the college. ${ }^{42}$ It was a time of great anxiety, uncertainty, frustrations and confusion. Matt Esau recalled the closure of St Paul's College as closely related to the changes that were taking place in the country. ${ }^{43}$

Esau's point is valid in that, partly, the emerging non-racial South African society prompted the leadership of the Anglican Church to consider establishing a new theological college not associated with the baggage of apartheid. As such, the history of St Paul's College and St Bede's Colleges had been too closely associated with apartheid. It was in this vein that Esau went on to assert that:

The demographics of the country [also] made it extremely difficult for non-racial students to go to St Paul's ... in the 1990s. [The college was] attracting fewer male white students ... What was also happening at that time ... [was that] ... the church was preparing women for ordination; [and] fewer white males [were] coming to the college but more white female ordinands ... For example, women in the second year, [when I was in the first year] were entirely white ... Partly [the closure] had to do with the race issue; and partly the political changes that were taking place ... ${ }^{44}$

The increasing number of women in the college reflected a shift in the ministerial training. It was a social and religious issue. The issue had social and religious dimensions precisely because both in society and in the church, women were already taking leading positions. Women were putting themselves forward for the ministry. Hewitt further observes that:

Near the end of 1991, the situation of the Colleges will be reviewed, and if one or more are not viable, a process of rationalisation could then begin. Our numbers dropped from about 50 in 1989 to 37 this year, there being only 8 in the first year class. Information from Dioceses leads me to anticipate even smaller first year [numbers] for 1991, but instead it has grown to nearly 20. This year, there are 18 leavers, so our numbers will remain constant. I thank God for this sudden new influx of students, and remain hopeful that we will be in business for some time! We are hoping that in 1991 our first year class will do their academic studies through Rhodes, individuals enrolling for degree or

42 Group interview with Victor Jones, Michael Bailey, Stafford Moses, and Margaret Vertue, Somerset West, 5 April 2016. 
diploma course as seems appropriate. There is no attempt to spite the Joint Board, and we will be maintaining links with them for a number of reasons. Rather, this is an opportunity to explore new avenues... ${ }^{45}$

In his Warden's Letter of December, 1990, Hewitt announced the resignation of Bikitsha Njumbuxa and Eddie Daniels joining the college staff. With regard to Njumbuxa he said: "We will miss him greatly; his loyalty and enthusiasm are great qualities and he has exercised pastoral ministry at the College which grew and grew. He has especially enjoyed this year, and should go out with happy memories of his rich giving." 46

However, developments regarding the closure of the College were moving faster. Philippe Denis and Graham Duncan noted that "in September 1991, ignoring the recommendations of the Provincial Commission on Theological Education that a two-year moratorium be set until a suitable venue for a new theological centre had been found-the Provincial Standing Committee decided to close St Bede's at the end of 1992 and to establish a new college which would incorporate St Paul's in Grahamstown."

\section{VISION AND PLANS FOR A NEW COLLEGE}

It was under these circumstances that, Hewitt announced that:

The College which will start on this campus in 1993 needs to be a new operation. I will therefore not be staying beyond the end of 1992, and that was discussed at P.S.C. It seems certain that none of the other full-time academic staff will be staying either, and it is likely that the college secretary and housekeeper will also resign. I think you will see why the meeting is an important one! The budget for next year is very difficult because of so many unknowns in the equation. ${ }^{48}$

45 Warden's Letter, December 1990, AB 2568, A 4, St Paul's College, 1983-91, Historical Papers, Research Archived, UWL.

46 Warden's Letter, December, 1990, AB 2568, A 4, St Paul's College, 1983-91. Historical Papers, Research Archived, UWL.

47 Philippe Denis and Graham Duncan, The Native School that Caused All the Trouble, Pietermaritzburg: Cluster Publications, 2011, p. 259.

48 Minutes of the Ordinary Meeting of the St Paul's College Council, 13 March, 1991, AB 2568, B 5, St Paul's College, 1987-92. Historical Papers, Research Archives, UWL. 
The idea of starting the new college as it were on a "clean slate" was noble but impractical. For the new college to succeed, it needed some form of continuity with the old. Critical issues to the college, such as budget and administrative staff, were indispensable and had to be carried on to the new college considering the experience of personnel acquired through years.

In the interim, on 13 March 1991, Hewitt presented his report to the College Council. In that report, he highlighted the financial state of the college and possible plans for the new college. He itemised the issues as follows:

a) Re- the rumoured report closure of St Paul after the two-year evaluation period, the warden noted that the Theological Education Commission earlier this year had not discussed the issue. A "monitoring Committee" was in place (Bp. David and Bp. Eric of Grahamstown and Bp. Dwane (OE).

b) Re- the financial situation of the colleges, the warden said that at present St Paul's College was in profit, aided by renting rooms and homesteads to Rhodes students. Other colleges were also surviving, but everything depended upon ordinand numbers for the year. With the Cape Town Zonnebloem idea and other diocesan initiatives, the future was very uncertain. It was also noted that ecumenical initiatives via the CUC and SACTE were looking into the wider theological training issues of the country ...49

Hewitt's reference to the diocesan initiatives is very significant. In the late 1980s and early 1990s, a diocese like Johannesburg started their own training schemes, Desmond Tutu School of Ministries. The presence of such schemes seemed to affect the number of ordinands who were being sent to the college.

The possible ordination of women to the priesthood increased anxiety and uncertainty in the college, which for years had been associated with merely male priesthood; the issue to which we now turn.

49 Minutes of the Ordinary meeting of St Paul's College Council, 19 March, 1991, (confidential), AB 2568, B 5, St Paul's College Theological College. Historical Papers, Research Archives, UWL. 


\section{THE ORDINATION OF WOMEN}

In his report to the College Council of 9 October 1991, Hewitt points out that:

This matter had been discussed on various occasions in the College since March, using Church and Society slots and a guest speaker. The presence of the Revd Suzanne Peterson as a boarder at the College had also aided receptivity to the idea and only one or two had absented themselves when she celebrated the Eucharist. Mr C. Hartnick echoed this and noted a good number of St Paul's College students at the Grahamstown Diocesan debate on the matter. ${ }^{50}$

Hewitt's report suggests some kind of resistance to the ordination of women in the college. The report and the students' response ought to be seen in light of the impact of the 1989 Provincial Synod Resolution on the college. The vote to ordain women had failed. In the aftermath of the vote, Hewitt recalled that "a few students [were] irritated by this decision, but many respected it." ${ }^{, 51}$ However, according to Hewitt, "Torquil Paterson deciding in protest not to preside at any further Eucharist until this issue was resolved ... Torquil maintained this position until he left the college to pursue his new career."52

Resistance to women ordination in the college must be seen within the broader context in the Anglican Church. Several grounds were advanced to justify the exclusion of women from the priesthood. Gloria Smith outlined some of them as follows: Anthropologically, the argument was raised that women and men were created to fulfil different roles in creation and society. ${ }^{53}$ From the point of view of history, it was argued that there was no precedent in the church tradition for ordaining women. ${ }^{54}$

Finally, the argument centred on the gender of Jesus Christ. Jesus Christ's maleness tended to be associated with the priesthood. ${ }^{55}$ The ordination of women was viewed as counter to Jesus

50 Minutes of the Ordinary Meeting of the St Paul's College Council, 9 October, 1991, AB 2568 B 5, St Paul's College, 1987-92. Historical Papers, Research Archives, UWL.

51 Personal communication with Chichele Hewitt, 20 December, 2016.

52 Personal communication with Chichele Hewitt, 20 December, 2016.

53 See for instance, Gloria Smith, "Response to the Ordination of Women as Priests in the Anglican (CPSA) Diocese of Pretoria, South Africa," Journal of Theology for Southern Africa, 109 (March 2001), 83-93.

54 Smith, Gloria, "Response to the Ordination of Women as Priests in the Anglican (CPSA) Diocese of Pretoria, South Africa," Journal of Theology for Southern Africa, no. 109 (2001): 83-89.

55 Smith, "Response to the Ordination of Women as Priests in the Anglican (CPSA) Diocese of Pretoria, South Africa." 
Christ presiding over the Passover (Eucharist). In this respect, the maleness of Jesus Christ was considered as representative for humanity. ${ }^{56}$ It is almost as if during the Lord's Supper, Jesus Christ only represented men.

The issue of the ordination of women to the priesthood was one which entailed power in the form of patriarchy. With the changing roles of gender in society, the church faced pressure to reconsider women's vocation, role and gifts in ministry. Women could no longer be denied a leadership role where this was affirmed in society. To some men in the church, however, this was a threat to their "power" and "authority." The presence of Rev Suzanne in the college was strategic, as it was meant to break down some barriers amongst students who would lead the church. It is one thing to see and experience, and another to imagine.

\section{THE PROPOSED CLOSURE OF ST PAUL'S COLLEGE}

The Minutes of the College Council of 9 October, 1991, noted Hewitt's report from the Provincial Standing Committee regarding the closure of the college thus:

The warden, in presenting the Provincial Standing Committee minute concerning the closure of St Paul's, gave a brief history of the process leading up to the resolution, noting proposals such as the focussing of all training at the Federal Seminary, the reaction to the loss of a rural college, the original proposal to close St Bede's and retain St Paul's College (made at Episcopal Synod), and the perception (at PSC) that this was a white college surviving at the expense of a black one. He concluded by mentioning the Archbishop's suggestion of a new venture on the Grahamstown campus, and how this had been followed up. The warden suggested that the problems outstanding concerned the psychological and logistical problems faced by both staff and students alike, combined with an inevitable deficit budget for $1992 .{ }^{57}$

The College Council received and endorsed the resolution of the Provincial Standing Committee to close St Paul's College and St Bede's. The new college would operate on St Paul's College premises. It is interesting to note that perceptions had been created that St

56 Smith, "Response to the Ordination of Women as Priests in the Anglican (CPSA) Diocese of Pretoria, South Africa."

57 Minutes of the Ordinary Meeting of the College Council, 9 October, 1991. AB 2568, B 5, 1987-92. Historical Papers, Research Archives, UWL. 
Paul's, a "white" campus would survive while St Bede's, a "black" college would cease existing. ${ }^{58}$ In these perceptions, the issue of apartheid came to the fore. To the people who saw things in that light, St Bede's had been sacrificed because it was a "black" sheep. Hewitt further notes that:

Thereafter discussion centred upon further issues concerning theological education, including dissatisfaction with the Federal Seminary amongst bishops (to be addressed by an episcopal visit there led by Bishop Bruce on 11th November 1991), the wounded reaction of Lelapa La Jesu upon being reduced to the status of a diocesan college, together with concern that Provincial initiatives were being threatened by local diocesan ones. There was also discussion concerning ways of reducing the budget deficit, by moving either college to the campus of the other for a year ... but the logistics suggested that this would be impractical. ${ }^{59}$

In addition, the report observes the following:

It was then proposed that representatives of St Paul's College and St Bede's Councils and students meet to prepare for the purpose of amalgamation etc. Further discussion concerned the reactions of St Paul's College students to the PSC resolution and implication and its implications. The head student mentioned uncertainty among students about the motivation of the resolution and a feeling that it would affect morale during the year ahead, although a meeting of a student delegation, with the Warden on 10/10/91 ought to clarify matters somewhat. Bishop David intimated that any apportioning of blame for the situation was inappropriate, but when questioned concerning who was taking responsibility for the process of transformation agreed that this remained unclear and determined to address the metropolitan to this effect. ${ }^{60}$

This culminated in the following resolution as noted in Hewitt's report:

58 Chichele Hewitt, "A History of St Bede's and St Paul's", John Suggit and Mandy Goedhals (eds.), Change and Challenge, Marshalltown: CPSA, 1998, p. 121.

59 Minutes of the Ordinary Meeting of the College Council, 9 October, 1991. AB 2568, B 5, 1987-92. Historical Papers, Research Archives, UWL.

60 Minutes of the Ordinary Meeting of the College Council, 9 October, 1991. AB 2568, B 5, 1987-92. Historical Papers, Research Archives, UWL. 
All the full time staff including himself would resign at the end of 1992 in order to enable the new college to commence without legacies from the past. It was likely that the College secretary and housekeeper would resign. ${ }^{61}$

While it makes sense for the warden and the staff to resign, it sounds very much unreasonable have to request the secretary of the college (Rita Macrae) to resign. One would have thought that a secretary with experience on the job would assist in the good start and progression of the new college. Hewitt continued to assert that:

... the implication of the PSC resolution was that St Paul's College Council would not be reappointed at the 1992 PSC. Bishop David mentioned the appointment of Revd. Canon M. Mpumlwana of the Order of Ethiopia, to head up a new "Pastoral Institute" that would run in tandem with the new college, though commencing in $1992 \ldots$ It was also mentioned that a candidate for the Wardenship of the new college had been approached and had been in consultation with Canon Mpumlwana re the relationship of the college to the Pastoral Institute. It was suggested that the new Principal ought not to be over involved in St Paul's College prior to its closure to avoid any impression of belonging there. However the need to know who the Principal was, and his/her ideas of staffing would give greater stability to the process and ought to be clarified in the immediate future, preferably before the Archbishop left the country. ${ }^{62}$

The practical details of transition became a necessity to allow smooth handing over of the administration. Since St Paul's College was also celebrating its anniversary that year, Hewitt announced preparations for the event. In this regard, Hewitt itemised the following issues:

A student committee was presently working on proposals for the year which, to date, included the following:

*An orientation week and speaker in February

* A longer Awards occasion, possibly over two days

61 Minutes of the Ordinary Meeting of the College Council, 9 October, 1991. AB 2568, B 5, 1987-92. Historical Papers, Research Archives, UWL.

62 Minutes of the Ordinary Meeting of the College Council, 9 October, 1991. AB 2568, B 5, 1987-92. Historical Papers, Research Archives, UWL. 
* A 90th Anniversary Ball later in the year, possibly combined with the Leavers' Dinner and a "handing over ceremony". Further ideas concerning transition arrangements were that the Episcopal Synod and even the Anglican Primates Conference be held in Grahamstown as a way of publicising the launch [of] the new college. ${ }^{63}$

Meanwhile in his Warden's Letter, he formally announced that St Paul's College would cease operating as it will merge with St Bede's on the present campus. He stated:

Dear Friends, as you will have heard by now, we are entering a very uncertain time in Theological Education. Provincial Colleges have all experienced a drop in numbers in recent years, and a process of rationalisation had to come. It has been decided to amalgamate St Bede's and St Paul's College and to create a new College on the old St Paul's College campus. The new College will probably be called the Peter Masiza College, and will begin its operation at the beginning of $1993 .^{64}$

The context in which a decision was made to create a new college was complex. It was prompted by the emerging socio-economic and political circumstances. Apartheid legislation was gradually dropping - as the new order was emerging. The emerging order needed a new college, with a new vision, new ethos and new model of theological training, hence the name Peter Masiza. Peter Masiza was the first black African priest in the Anglican Church ordained in 1870 . Hewitt went on to assert that:

The Peter Masiza College needs an entirely fresh start, and a new principal is in the process of being appointed. It is also time for me to do something different; I have been warden since 1986, and at the College since 1984. I am too much a part of the present order to be able to give a new College a fresh start. I will therefore be leaving when the new principal takes up his appointment. He will appoint a new staff, and there is the prospect of a new and exciting phase opening in Theological Education. Obviously next year will be difficult in terms of the transition, but we are positive about it. It is the $90^{\text {th }}$ anniversary of St Paul's, and Matt Esau, our new senior student, has a small committee

63 Minutes of the Ordinary Meeting of the College Council, 9 October, 1991. AB 2568, B 5, 1987-92. Historical Papers, Research Archives, UWL.

64 Warden's Letter, 10 December, 1991, AB 2568, A 4, St Paul's College, 1983-91. Historical Papers, Research Archives, UWL. 
which is already planning ahead. The Archbishop will be our speaker at the Award Ceremony on 20 March, and once again we have just confirmed good end of the year results. ${ }^{65}$

Symptomatic of the change, the head of the college would no longer be called the "warden" but rather the "rector". Luke Lungile Pato became the first black rector appointed to head the college that became the College of the Transfiguration (COTT). Meanwhile, the College Council meeting on 9 October 1991 finally resolved the closure of the college. Hewitt reported the resolution in this manner:

\section{3:1 Report on the financial monitoring committee}

After clarifying the nature of conflated Theological Education Committee, Bishop Bruce [Evans] explained the initial proposals for rationing theological education, mentioning scenarios such as the closure of St Bede's, St Paul's College and Lelapa la Jesu, in favour of a new college at Zonnebloem in Cape Town ... ${ }^{66}$

The consideration of Zonnebloem was historically significant. Zonnebloem was associated with the Archbishop's role in training the early ordinands in the Cape.

\section{THE PROTEST OUTSIDE THE CATHEDRAL IN 1992}

During the very last years of the existence of St Paul's, the college body became much more socially and politically engaged. The college started the year 1992 with a protest march. Hewitt reported to the College Council as follows:

In other ways, too, the year got off to a good start. The senior student of the College, Mr M. Esau, put together a creative orientation programme for the first week of term, which included a visit to the local township. This coincided with the ugly event of the township water being cut off as a result of the dispute between the Grahamstown town council and the Rini town council. Students and staff felt strongly enough about this to

65 Warden's Letter, 10 December, 1991, AB 2568, A 4, St Paul's College, Warden's Letters, 1983-91 [emphasis, original]. Historical Papers, Research Archives, UWL.

66 Minutes of the ordinary meeting of the St Paul's College Council, 9 October, 1991, AB 2568, B 5, St Paul's College Council Minutes, 1987-92. Historical Papers, Research Archives, UWL. 
join with the Bishop in making representations to the Town Clerk, and holding a poster demonstration outside his offices. This led to the arrest almost of the entire community, and their release a few hours later. ${ }^{67}$

Commenting on this incident, Bob Clarke stated that following the rioting, cars were stoned "in the main road linking town and township, the Bishop of Grahamstown, the principle and the entire student body of St Paul's Theological College protested outside the city hall only to be arrested for staging an 'illegal' gathering." 68

\section{THE PROVINCIAL RESOLUTION TO CLOSE ST PAUL'S COLLEGE AND ST BEDE'S COLLEGE}

In his Warden's Report of early 1992 to the council, Hewitt gave a very extensive report in which he covered wide-ranging issues. These issues reflected the major changes that the college was going through. Under the heading, "The College Now", Hewitt highlights that:

The first factor concerns the so-called De Klerk initiatives of 1990. Perceptions of these obviously vary in the country and in this community, but they have acted as some sort of a pressure valve which has decreased the intensity of racial feeling that we have experienced in the College in the past.

This is very significant considering that for the first time in the history of the college, white and black students now started feeling they had the same destiny. De Klerk's initiatives seemed to have had a unifying factor in the college. In addition, Hewitt stated the following:

The second relates to the racial composition of the College, while it may be undesirable to draw attention to such things, I do so for two reasons. If one includes our colleagues from the Order of Ethiopia, the student body is almost $80 \%$ Black. Apart from the fact that this is more or less representative of where the country is, it has firstly relieved the tension. When the College was more or less 50-50 White-Black there was a ceaseless

67 Warden's Report, College Council minutes (confidential), 19 March, 1982. AB 2568 B 5, St Paul's College, $1987-92$. Historical Papers, Research Archives, UWL.

68 Bob Clarke, Anglicans against Apartheid, 1936-1996. Pietermaritzburg: Cluster Publications 2008, p. 500. 
power struggle in College life. This has become less extreme, coincident with the effect of the new initiatives in the country.

Under the heading, "The future of the new provincial seminary", Hewitt states:

I have another reason, however, for mentioning the racial composition of the College. There is a pathetic bleating in the C.P.S.A about St Paul's College being a White college. Now of course this has to be taken seriously. Only 3 years ago we managed to eradicate from our constitution the phrase about St Paul's College being a college for training "European males". Apart from the total embarrassment of such a racial phrase, it has since the mid-70s become increasingly untrue. One might add that it is blatantly sexist, and that this year we are "training" more "European females" than "European males" which has its own special significance. One might also ask what has happened to the supply of "European males" coming forward for ordination?

Then Hewitt continued to assert that:

But returning to the White college issue. The accusation has some truth. The staff, parttime are overwhelmingly White, and that will presumably change at the end of this year. I made the point at P.S.C that it is time that the College had a Black principal, and that, too, will be happening from the end of this year. (In terms of creative change, and as to where South Africa is moving, and I am not the person to make it.) Our theological training and academic background as staff is undeniably 'Eurocentric'. With all our new initiatives in music and chapel worship in the right direction, our ethos remains Western. None of these things can be denied.

It would seem very little had changed since the outcry in 1982 that the ethos and structure of St Paul's College were predominantly white. St Paul's College was very much training ordinands in the Western model. Hewitt further asserted:

Yet it is high time that those who make such accusations do so from an informed position. If they were to come to St Paul's, they may see something different. They would experience worship which is becoming increasingly African, and in which a number of languages are used. (Here I might complement my colleague, the Revd. John 
Thomson for the initiatives he has taken in learning Xhosa). They will experience the subtle shifts in harmony that suggest the emergence of a new tradition, despite the interesting preference for Victorian music within college student body. They will experience a community ethos which is taking its own authentic shifts in the right direction of a truly African spirituality. If the other residential Colleges can be called Black, so can we. I strongly suspect, however, that if we are still "Western" then so are they! 69

It is indeed the case that perceptions die hard. Even after some significant changes had taken place in the African ethos, some people still saw St Paul's College as a "European College". It would seem that they refused to acknowledge these developments or deliberately ignored them. To a greater extent, St Paul's College had become African-oriented in its ethos. Thompson's efforts to learn IsiXhosa would suggest this. But then one also wonders: why did it have to take Thompson, just arrived from England to learn IsiXhosa? For the entire four years that this author was a student at the college, no lecturer tried to learn IsiXhosa!

Hewitt then portrayed a gloomy picture of the state of the college when he said that " $t]$ he proposed closure of St Paul's College at the end of 1992 has dominated much of our thinking over the past year [i.e. 1991]." In that report, he continued to talk about the drop in numbers. Thus, Hewitt asserted:

Ironically the numbers at St Paul's College have increased in 1992. There were 33 students at the start of 1991, and at the beginning of this year there were 32 . When one counts in the $\mathrm{O}$ of $\mathrm{E}$ (Order of Ethiopia) members, however, the number stands at 38. So far the relationship has worked happily.

Then under the heading, "Reactions to the Closure of St Paul's", Hewitt reports that:

It would not be true to say St Paul's College welcomes its own closure, and the amalgamation with St Bede's College. The inevitability of rationalization was understood, but nobody likes to see the demise of an institution, especially during the year in which it celebrates its 90th anniversary! We are, however, grateful to the Bishop

69 Warden's Report, (March) 1992. AB 2568, B 5, 1987-92. Historical Papers, Research Archives, UWL. 
of Grahamstown for the level of communication which he has maintained with staff and students at the College. The day after PSC closed, Bishop David [Russell] informed the College of P.S.C's decision, and he has regularly kept in touch with individual staff members. This has greatly assisted in obvious hurts which have been evident with amongst all residential seminary staff, and which has been exacerbated by lack of information throughout the Province resulting in speculation and rumour. In this regard we are also grateful to the Dean of the Province for the initiatives he took in bringing together representatives of the two Colleges recently. ${ }^{70}$

It was under these circumstances that on 6 October 1992, Hewitt wrote his last letter as warden as follows:

This will be the last time I write to you as warden of St Paul's College, and in fact the last time you will probably receive mail from St Paul's College, before it becomes the new College of the Transfiguration. Some of us will attend the closing ceremonies of St Bede's on Sunday 1 November, and then some St Bede's folk attend our ceremonies 2 days later. From the beginning of next year, the two colleges amalgamate. ${ }^{71}$

Equally significant was that the start of the new college was given an international context. Hewitt announced that:

a) The opening ceremonies are timed to coincide with a visit from the heads of the Anglican Church in various parts of the world. From the old collage I am humbled as I look back on my predecessors. My years as the last warden of the old college have been hard, but good. It has been a time of particular transitions (there have been many different transitions), and importantly we have held together when so much roundabout has not. Our worship, with its ups and downs, has been a key factor, and I am delighted that the new full college has an extended chapel ... Important alterations have been made in the place where it most matters. We assure the new rector, the Revd. Luke Pato, and his staff, of our prayers and

70 Warden's Report, (March) 1992. AB 2568, B 5, 1987-92. Historical Papers, Research Archives, UWL.

71 Warden's Letter 6 October 1992, AB 2568, A 4 1983-1991; St Paul's College. Historical Papers, Research Archives, UWL. 
good wishes in the years ahead, and we look forward to seeing as many of you as possible on Tuesday, 3 November, $1992 .{ }^{72}$

With this arrangement, the way now opened for the establishment of the new college. Thus, in February 1993, the new college was finally officially opened. Not Peter Masiza, as it had earlier been thought, the new college was given a name: College of the Transfiguration of Our Lord, in short COT. The name seemed racially neutral as it neither belonged to a "white" saint nor a "black" saint. According to Chichele Hewitt, "the name of College of the Transfiguration was chosen, influenced by Archbishop Tutu who has always been fascinated by this event."73 The name seemed more appropriate as it seemed to signify the start of new beginnings in theological training from the ruins of the old colleges of St Bede's and St Paul's.

However, the establishment of the new college on the premises of what was then St Paul's College soon gave the impression, at least to others, that after all the new college was just the old St Paul's College with a new name. Whatever misgivings some people might have had, in its $92^{\text {nd }}$ year, the old St Paul's College ceased to operate with all its traditions and ethos which defined its identity. A new college with a new identity had come.

\section{CONCLUSION}

This article has highlighted the history of St Paul's Theological College during the last six years of its existence. Specifically, it has illustrated the impact of the socio-political and religious issues on its life, as follows: the increase of black male ordinands just as more white women ordinands were starting to come into college for training. The paper has also illustrated that in the atmosphere of the transition to democracy, the college became more involved in the socio-economic and political issues that affected the surrounding communities and in the country. The future of the college seemed uncertain as it struggled with finances; sometimes amidst the fluctuating numbers of ordinands. Amongst others, uncertainty regarding traditional theological pedagogy and methods of training, its historical legacy, increased its sense of uncertainty, seemed to strengthened the reasons for the college (along with St Bede's Theological College) to give way to the opening of a new college on the same premises called the College of the Transfiguration (COT).

\footnotetext{
72 Warden's Letter, 6 October, 1992, AB 2568, A 4 1983-91, St Paul's College. Historical Papers, Research Archives, UWL.

73 Chichele Hewitt, “A History of St Bede's and St Paul's", p. 121.
} 


\section{REFERENCES}

Clarke, Bob. Anglicans against Apartheid, 1936-1996. Pietermaritzburg: Cluster Publications, 2008.

Corbett, Ian D. "Homosexuality in the Traditions of the Church." In Aliens in the Household of God, edited by Paul Germond and Steve de Gruchy. Cape Town and Johannesburg: David Philip, 1997.

Denis, Philippe and Graham Duncan. The Native School that Caused All the Trouble.

Pietermaritzburg: Cluster Publications, 2011.

Hewitt, Chichele. “A History of St Bede's and St Paul's.” In Change and Challenge, edited by John Suggit and Mandy Goedhals. Marshalltown: CPSA, 1988.

Hinchliff, Peter. The Anglican Church in South, London: Darton, Longman \& Todd, 1963.

Naidoo, Marilyn. "Ministerial Training: The need for Pedagogies of Formation and of Contextualisation in Theological Education." Missionalia, no. 3 (2010): 347-368.

Smith, Gloria. "Response to the Ordination of Women as Priests in the Anglican (CPSA) Diocese of Pretoria, South Africa." Journal of Theology for Southern Africa, no. 109 (2001): 83-89.

Tutu, Desmond. "Foreword." In Aliens in the Household of God, edited by Paul Germond and Steve de Gruchy. Cape Town and Johannesburg: David Philip, 1997.

\section{INTERVIEWS}

Group interview with Victor Jones, Michael Bailey, Stafford Moses, and Margaret Vertue, Somerset West, 5 April 2016.

Interview with Douglas Torr, Bramley, Johannesburg, 12 June, 2014.

Interview with Matt Esau, UCT, 15 March, 2016.

Personal communication with Chichele Hewitt, 20 December, 2016.

Skype Interview with Torquil Paterson, 2 March, 2016.

Telephone interview with Chichele Hewitt, 17 March, 2016.

Telephone interview with Chichele Hewitt, 17 May 2016.

\section{ARCHIVES}

ACT X, Constitution and Trust Deed of St Paul's College, AB 2568 B 4, 1983-86. Historical Papers, Research Archives, UWL.

Minutes of the Ordinary Meeting of the St Paul's College Council, 13 March, 1991, AB 2568, B 5, St 
Paul's College, 1987-92. Historical Papers, Research Archives, UWL.

Minutes of the Ordinary meeting of St Paul's College Council, 19 March, 1991, (confidential), AB 2568, B 5, St Paul's College Theological College. Historical Papers, Research Archives, UWL.

Minutes of the Ordinary Meeting of the St Paul's College Council, 9 October, 1991, AB 2568, B 5. St Paul's College Council Minutes, 1987-92.

University of Witwatersrand, Library (UWL). Historical Research Papers AB 2568, A 4, St Paul's College Theological College, 1983-91.

Warden's Report, College Council Minutes (confidential), 19 March, 1982. AB 2568 B 5, St Paul's College, 1987-92.

Warden's Letter, 27 November, 1986, AB2568, A 4, St Paul's College, 1983-91. Historical Papers, Research Archives, UWL.

Warden's Letter, August, 1987. AB 2568, A 4, 1983-91. Historical Papers, Research Archives, UWL.

Warden's Report, Council Minutes, February, 1988, AB2568, A 4, St Paul's College, 1987-92. Historical Papers, Research Archives, UWL.

Warden's Report, 18 February, 1990, Minutes of St Paul's College Council, 15 March, 1990, AB 2568. Historical Papers, Research Archives, UWL.

Warden's Letter 6 October 1992, AB 2568, A 4 1983-1991.Warden's Report, (March) 1992. AB 2568, B 5, 1987-92. 